\title{
Different plant traits affect two pathways of riparian nitrogen removal in a restored freshwater wetland
}

\author{
A. E. Sutton-Grier • J. P. Wright • C. J. Richardson
}

Received: 11 October 2011 / Accepted: 19 December 2011 /Published online: 4 February 2012

(C) Springer Science+Business Media B.V. 2012

\begin{abstract}
Background \& aims Plants may have dissimilar effects on ecosystem processes because they possess different attributes. Given increasing biodiversity losses, it is important to understand which plant traits are key drivers of ecosystem functions. To address this question, we studied the response of two ecosystem functions that remove nitrogen $(\mathrm{N})$ from wetland soils, the accumulation of $\mathrm{N}$ in plant biomass and denitrification potential (DNP), to variation in plant trait composition.

Methods Our experiment manipulated plant composition in a riparian wetland. We determined relative
\end{abstract}

Responsible Editor: Jeff R. Powell.

Electronic supplementary material The online version of this article (doi:10.1007/s11104-011-1113-3) contains

supplementary material, which is available to authorized users.

A. E. Sutton-Grier $(\bowtie)$

Nicholas School of the Environment and Earth Sciences,

Duke University,

Box 90328, Durham, NC, USA

e-mail: ariana.suttongrier@gmail.com

J. P. Wright

Biology Department, Duke University,

Box 90338, Durham, NC, USA

e-mail: justin.wright@duke.edu

C. J. Richardson

Nicholas School of the Environment and Earth Sciences,

Duke University,

Box 90333, Durham, NC, USA

e-mail: curtr@duke.edu importance of plant traits and environmental variables as predictors of each ecosystem function.

Results We demonstrate that Water Use Efficiency (WUE) had a strong negative effect on biomass $\mathrm{N}$. Root porosity and belowground biomass were negatively correlated with DNP. Trait ordination indicated that WUE was largely orthogonal to traits that maximized DNP.

Conclusions These results indicate that plant species with different trait values are required to maintain multiple ecosystem functions, and provide a more mechanistic, trait-based link between the recent findings that higher biodiversity is necessary for multi-functionality. While we selected plant traits based on ecological theory, several of the plant traits were not good predictors of each ecosystem function suggesting the ecological theory linking traits to function is incomplete and requires strengthening.

Keywords Biodiversity and ecosystem function . Denitrification potential (DNP) · North Carolina · Plant traits $\cdot$ Wetland restoration
Abbreviations
AGB aboveground biomass
AGCN aboveground biomass carbon to nitrogen ratio
BEF biodiversity and ecosystem function
BGB belowground biomass 


$\begin{array}{ll}\text { BGCN } & \begin{array}{l}\text { belowground biomass carbon to } \\ \text { ratio }\end{array} \\ \text { BGR } & \text { Below-ground Rooting Ratio } \\ \mathrm{C} & \text { carbon } \\ \mathrm{CO}_{2} & \text { carbon dioxide } \\ \mathrm{DEA} & \begin{array}{l}\text { Denitrification Enzyme Assay } \\ \text { DNP }\end{array} \\ \text { denitrification potential } \\ \mathrm{N} & \text { nitrogen } \\ \mathrm{NH}_{4}-\mathrm{N} & \text { extractable ammonium } \\ \mathrm{NO}_{3}-\mathrm{N} & \text { extractable nitrate+ nitrite } \\ \mathrm{POR} & \text { root porosity } \\ \mathrm{SEM} & \text { structural equation modeling } \\ \mathrm{SLA} & \text { specific leaf area } \\ \text { SRL } & \text { specific root length } \\ \text { WUE } & \text { water use efficiency }\end{array}$

\section{Introduction}

The planet is facing numerous anthropogenic stresses including climate change, eutrophication, invasive species introductions, and habitat loss (Houghton et al. 2001; Mack et al. 2000; Millennium Ecosystem Assessment 2005; Vitousek 1997). These stresses are changing the distribution and abundance of species worldwide (Dukes 2000; Owensby et al. 1999; Sutherst 2000) which in turn can alter ecosystem functioning (Balvanera et al. 2006; Cardinale et al. 2006; Hooper et al. 2005; Naeem and Wright 2003). In order to better manage our natural resources and mitigate undesirable future changes, it is critical that we understand the effects of different organisms on ecosystem processes (Chapin 2003). Because species vary in the trait values, or ecophysiological and morphological attributes they possess, plant species differentially influence ecosystem functioning (Chapin et al. 2000; Wardle 2002). Given that differences in physiology, morphology, and phenology between species have important effects on ecosystem functioning, traitbased ecology has been proposed as a method for providing a mechanistic link between species and ecosystem functions (Chapin et al. 1996; Diaz and Cabido 1997; Diaz et al. 2004; Wardle et al. 1998).

One challenge in trait-based ecology is determining which traits are related to particular ecosystem functions of interest (Lavorel and Garnier 2002; McGill et al. 2006; Suding et al. 2008; Westoby and Wright 2006). As we continue to develop our understanding of how plant traits influence ecosystem functioning, ecological theories about the mechanistic links between traits and ecosystem functioning can inform hypotheses which can then be tested with field data (see the sections on "Linking traits to biomass $\mathrm{N}$ or denitrification"). Although some plant traits vary independently (e.g., Eviner 2004), many plant traits are correlated (e.g., Diaz et al. 2004; Reich et al. 2006) which makes simple experimental tests more difficult. As a result, analytical methods that account for these correlations between traits are critical.

A second challenge is understanding how important plant traits are to regulating ecosystem processes relative to environmental factors such as soil resource levels. Biodiversity and ecosystem function (BEF) studies have shown that changes in plant composition can affect plant productivity or nutrient cycling (Callaway et al. 2003a; Engelhardt and Ritchie 2001; Hector et al. 1999; Tilman et al. 1997; Tilman et al. 2001; Zak et al. 2003). But the importance of plant traits relative to environmental factors is not clear. For example, nutrient cycling in ecosystems is strongly controlled by environmental parameters, but can also be influenced by both plant (Fornara and Tilman 2008; Fornara et al. 2009; Templer et al. 2003) and microbial communities (Cavigelli and Robertson 2000; 2001; Wittebolle et al. 2009). Plants impact microbial processes largely by changing the soil environment in which the microbes live and compete via inputs of plant carbon (C), for example (Farrar et al. 2003; Wardle 2002). While the influence of plant traits, such as the $\mathrm{C}$ to nitrogen $(\mathrm{N})$ ratio of plant tissue inputs, on the process of decomposition has been relatively well studied (Cornwell et al. 2008), the influence of plant traits on other microbial processes, including denitrification, are less well understood particularly as compared to the importance of environmental drivers on these processes.

There is also increasing evidence from BEF studies that more diverse communities are better able to maintain multiple ecosystem functions (Duffy 2009; Gamfeldt et al. 2008; Hector and Bagchi 2007). This means that although there may be redundancy in species trait values that support one particular ecosystem function, there is generally much less multifunctional redundancy in the entire community (Gamfeldt et al. 2008). But this assumption that greater trait diversity leads to multifunctionality needs to be tested.

In this study, we examine two ecosystem functions in a restored riparian wetland. One of the primary 
goals of many riparian restoration efforts is the removal of $\mathrm{N}$ from the system to minimize export to adjacent aquatic systems. There are two primary pathways (i.e. processes) by which $\mathrm{N}$ can be removed from groundwater; plant uptake of soil $\mathrm{N}$ and subsequent incorporation into biomass and microbial denitrification, the process by which facultative anaerobic microbes convert nitrate to $\mathrm{N}_{2}$ gas using organic $\mathrm{C}$ as an energy source. The latter pathway is microbially-mediated but also indirectly affected by the plant community inputs of carbon and oxygen to the soil. Given the potential links between these two functions, it is a particularly interesting question whether multiple plant species are necessary to maximize these two N-removing ecosystem functions and what plant traits might affect these processes.

We examine the relationship between functional plant traits, environmental variables, and two ecosystem functions: (1) biomass $\mathrm{N}$, defined as the grams of $\mathrm{N}$ in aboveground biomass, and (2) potential denitrification (DNP). We ask first, 'Do plant traits significantly affect biomass $\mathrm{N}$ and DNP independent of the effects of environmental variables?' If traits do impact ecosystem function, we ask, 'Which specific traits controls these function?' We also ask, 'Are plant traits or environmental variables more important predictors of each ecosystem function?' Based on the results of our plant trait analysis, we examine whether there are certain combinations of traits and/or species that maximize biomass N, DNP, or both functions. In other words, from an ecosystem management perspective, we ask, 'Are the traits controlling different functions tightly correlated across species or are species with different sets of traits necessary to maximize multiple ecosystem functions?'

\section{Materials and methods}

Conceptual model

\section{Linking traits to biomass $N$}

Biomass $\mathrm{N}$ is a function of both plant productivity and the $\mathrm{C}: \mathrm{N}$ ratio of the plant biomass. In ecosystems such as riparian wetlands, with high nutrient fluxes and high productivity (Mitsch and Gosselink 2000), even plants with high $\mathrm{C}: \mathrm{N}$ can have high relative growth rates and sequester large amounts of $\mathrm{N}$. Because we assume this relatively tight relationship between productivity and biomass $\mathrm{N}$, our hypotheses are mainly focused on predicting standing crop production. We hypothesize that traits associated with high growth rates will lead to increases in biomass $\mathrm{N}$ (Cornelissen et al. 2003). More specifically, we hypothesize that plants could affect biomass $\mathrm{N}$ through two categories of traits: 1) resource capture and use (Water Use Efficiency-WUE; Specific Root Length-SRL; and Specific Leaf Area-SLA), or 2) through different plant architectural growth strategies above and belowground (Plant Height and Below-ground Rooting Ratio-BGR). See Table 1 for the definitions and justification for each trait we selected. Although WUE may seem a counterintuitive trait to measure on wetland plants, the hydrology of riparian wetlands is largely driven by precipitation inputs which can mean that soils have no standing water and are not saturated for significant parts of the growing season (Mitsch and Gosselink 2000). At our study site, we observed relatively dry soil conditions (on average between $17 \%$ and $35 \%$ moisture by weight) with no standing water in any of our plots for the majority of the growing season. Thus, WUE of the plants may likely play a more important role in driving plant impacts on ecosystem processes.

\section{Linking traits to denitrification potential}

Soil conditions, such as soil $\mathrm{N}$ and soil $\mathrm{C}$, have been shown to be important drivers of denitrification rates (Drury et al. 1991; Ettema et al. 1999; Groffman 1994; Groffman and Crawford 2003; Lowrance and Hubbard 2001), and can potentially be affected by plant traits. Other studies have found that specific types of plants, such as annuals, and specific species, such as Typha latifolia, influence denitrification enzyme activity (Crush 1998; Hernandez and Mitsch 2007; Hume et al. 2002; Lin et al. 2002; Patra et al. 2006; Pinay et al. 2007). We hypothesize that plants are likely to influence denitrification mainly via their $\mathrm{C}$ inputs both in terms of $\mathrm{C}$ quantity and quality, both of which have been shown to limit denitrification (Groffman et al. 1991; Groffman and Crawford 2003; Hernandez and Mitsch 2007; Hill 1996; Hill and Cardaci 2004; Schipper et al. 1994). Plants may also affect denitrification through modification of the redox conditions in the soil via root delivery of oxygen through radial oxygen loss. Therefore, we selected five traits to 
measure related to each of these three categories. For $\mathrm{C}$ Quality we measured 1) Belowground $\mathrm{C}: \mathrm{N}$ ratio (BGCN), and 2) Aboveground $\mathrm{C}: \mathrm{N}$ ratio (AGCN) which represent the 'quality,' or relative amount of energy, in plant inputs to soils (Eviner and Chapin 2003). For C quantity we collected aboveground biomass (AGB) near the end of each growing season, and root biomass (BGB) from our soil cores each time we sampled. For soil redox status we measured root porosity to estimate the amount of oxygen that could be transported through the root system of each plant to the soil. See Table 2 for details about each denitrification trait we selected. It is important to recognize that due to difficulties with measuring denitrification in the field, we measured rates of denitrification potential in the lab. Measurements of denitrification potential do not necessarily correspond to field rates of denitrification (Groffman 1987; Martin et al. 1988; Parsons et al. 1991) but have been shown to give the clearest indications of differences in treatments because denitrification potential measurements are sensitive to changes in factors that control denitrification such as soil C availability (Groffman 1987; Groffman et al. 1999).

\section{Assumptions about traits of mixtures}

A great deal of research has focused on understanding the role of biodiversity on ecosystem function (see reviews in Balvanera et al. 2006; Cardinale et al. 2006). In terms of maintaining ecosystem function, however, the functional traits (those traits that affect functions of interest) of individual species are likely to be at least as important as the diversity of traits (Grime 1998; Hooper and Vitousek 1997). Grime (1998) proposed a 'mass-ratio' theory which suggests that "the extent to which plant species affect ecosystem functions is likely to be closely predictable from its contribution to the total plant biomass." It follows from this theory that ecosystem properties will be determined largely by the characteristics of the dominant species (Grime 1998). Therefore, in this study we examine the influence of biomass-weighted average plant traits on ecosystem functions that remove $\mathrm{N}$.

\section{The construct models}

Although some plant traits vary independently (Eviner 2004), many plant traits are correlated (Diaz et al. 2004; Reich et al. 2006; Wright et al. 2004) which 
Table 2 Categories of traits through which plants could affect denitrification. Categories include the measured trait and the justification for the trait choice including any proposed mechanisms by which the trait will impact denitrification

\begin{tabular}{|c|c|c|}
\hline Category & Measured Traits & Justification for Trait Choice \\
\hline \multirow[t]{2}{*}{ Carbon Quantity } & $\begin{array}{l}\text { 1)Aboveground biomass } \\
\text { (AGB), g }\end{array}$ & $\begin{array}{l}\text { Greater plant productivity aboveground will increase the quantity of plant litter } \\
\text { inputs to soil and hence soil carbon availability for denitrifiers (Diaz 2001). }\end{array}$ \\
\hline & $\begin{array}{l}\text { 2)Belowground biomass } \\
\text { (BGB), g }\end{array}$ & $\begin{array}{l}\text { Greater plant productivity belowground will increase belowground nutrient flux } \\
\text { (Chapin et al. 1996) as well as the quantity of plant root exudates (Farrar et al. } \\
\text { 2003) and root turnover to soil and, hence, soil carbon available for denitrifiers. }\end{array}$ \\
\hline \multirow[t]{2}{*}{ Carbon Quality } & $\begin{array}{l}\text { 1) } \mathrm{C}: \mathrm{N} \text { ratio of roots } \\
(\mathrm{BGCN}) \text {, unitless }\end{array}$ & $\begin{array}{l}\text { Lower C:N ratios make plant inputs of higher quality (Burke et al. 1998) so roots } \\
\text { are more easily decomposed by microbes, providing needed carbon to denitrifiers. }\end{array}$ \\
\hline & $\begin{array}{l}\text { 2) } \mathrm{C}: \mathrm{N} \text { of aboveground } \\
\text { biomass } \\
\text { (AGCN), unitless }\end{array}$ & $\begin{array}{l}\text { As described under C: } \mathrm{N} \text { of roots, leaf litter inputs of higher quality (i.e. that are } \\
\text { more easily decomposed by microbes) can provide needed carbon to stimulate } \\
\text { denitrifiers (Chapin et al. 1996; Diaz 2001; Melillo et al. 1982). }\end{array}$ \\
\hline Redox & $\begin{array}{l}\text { 1)Root porosity } \\
\text { (POR), unitless }\end{array}$ & $\begin{array}{l}\text { Increased POR could bring } \mathrm{O}_{2} \text { to the rooting zone which might inhibit denitrification, } \\
\text { or it could promote } \mathrm{NO}_{3}{ }^{-} \text {production in the root zone (Cronk and Fennessy 2001; } \\
\text { Ehrenfeld et al. 2005; Reddy et al. 1989) which could then diffuse to the adjacent } \\
\text { anaerobic zone and stimulate denitrification. In anaerobic wetland soils, POR is likely } \\
\text { to stimulate nitrification and result in greater denitrification. }\end{array}$ \\
\hline
\end{tabular}

makes simple experimental tests more difficult. Soils variables also tend to be correlated, therefore, analytical methods such as structural equation modeling (SEM), that account for these correlations, are useful (McCune and Grace 2002). In this study, we developed two proposed (construct) models, one for biomass $\mathrm{N}$ and one for denitrification potential (Fig. 1a and $b$ ). The construct models include both plant traits and environmental factors because we hypothesize that both are important predictors of ecosystem function. In these construct models we hypothesized that soil properties (soil $\mathrm{N}$ and soil $\mathrm{OM}$ ) were correlated to each other and that plant traits were correlated to each other. Although traits can vary with environmental conditions (Callaway et al. 2003b), for simplicity we followed the typical convention of assuming a single trait value for each species (Diaz and Cabido 1997; Diaz et al. 2004; Wright et al. 2004).

\section{SWAMP study area and experimental design}

The Duke University Stream and Wetland Assessment Management Park (SWAMP) is located along Sandy Creek in the Duke Forest in Durham, NC $\left(36^{\circ} 00^{\prime} \mathrm{N}\right.$, $\left.78^{\circ} 54^{\prime} \mathrm{W}\right)$. Soils are primarily Cartecay silt loams and Mayodan sandy loams (Kirby 1971). The site is a riparian wetland formerly dominated by Acer rubrum (red maple), Liriodendron tulipifera (tulip poplar), and Liquidambar styraciflua L. (sweet gum). In 2004, the wetland and stream were extensively restored to address water quality issues. In the process of restoration, all riparian vegetation was removed and the site was graded to a constant elevation. In the process of restoration, soils were homogenized as much as possible, however, soils are naturally heterogeneous and some degree of variation in soil resources remained even after soils were graded and homogenized.

The study site was located adjacent to the SWAMP restored stream in the riparian wetland. Fifty-one $2 \times$ $2 \mathrm{~m}$ plots were planted in May 2005 with a total of 100 seedlings (added as plugs) with different mixtures of species selected from a pool of 10 species. The species in the study (see list in Table 3) were selected from a list of recommended species for North Carolina stream restoration (Hall 2003) based on commercial availability and to maximize trait diversity. For more details of the study design and general soil properties at the site see Sutton-Grier et al. (2011).

\section{Soil sampling and laboratory analysis}

Soil samples were collected in the second growing season of the experiment, 2006, in May, July, and late August. Two soil samples ( $2.5 \mathrm{~cm}$ diameter) from each plot were collected in plastic sleeves from the upper $15 \mathrm{~cm}$ of each plot using a piston corer. Due to multiple sampling dates and other uses of the experimental plots, more extensive sampling was not possible. These samples were stored on ice and transported back to the lab 
a

\section{Biomass N Construct Model}

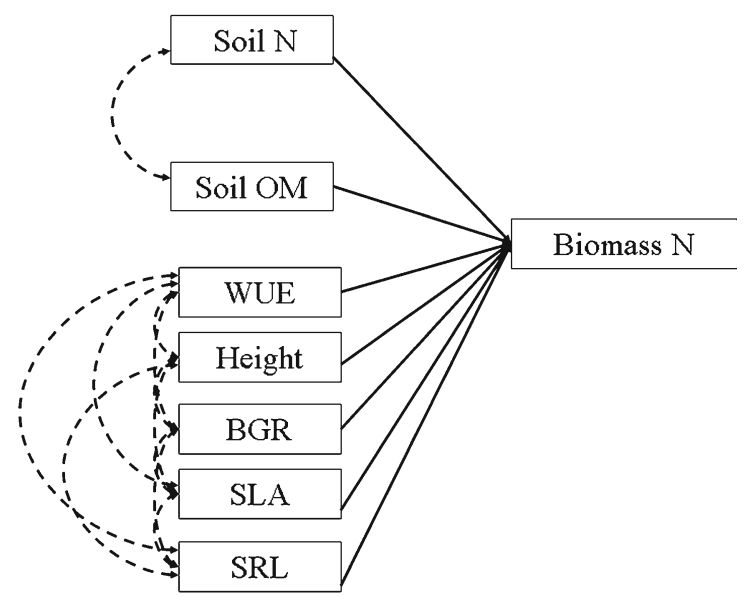

b

\section{Denitrification Potential Construct Model}

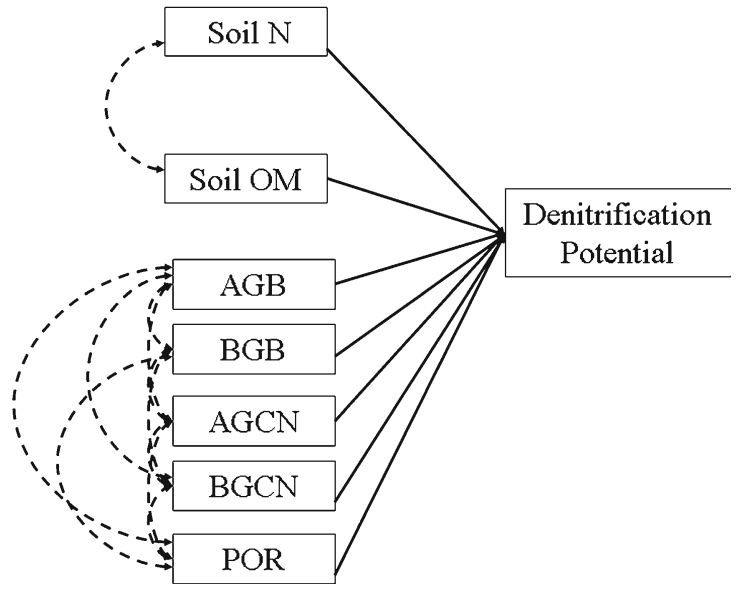

Fig. 1 Construct Models for (a) biomass N and (b) denitrification potential. Correlations are curved, dashed lines while direct paths are solid, straight lines

where they were stored at $4{ }^{\circ} \mathrm{C}$ until they could be analyzed (typically within a week of collection).

Upon arrival at the laboratory, the two cores from each plot were bulked together and sieved through a $4.75 \mathrm{~mm}$ sieve prior to analysis. All roots that would not pass through the sieve as well as roots that were easily removed by visual inspection were collected from each soil sample, briefly rinsed in DI to remove soil, dried at $60^{\circ} \mathrm{C}$, and then weighed to estimate belowground biomass within each plot. A sub-sample of each soil was oven dried at $105^{\circ} \mathrm{C}$ for $24 \mathrm{~h}$ to determine the moisture content, and dry soil conversions were used to calculate

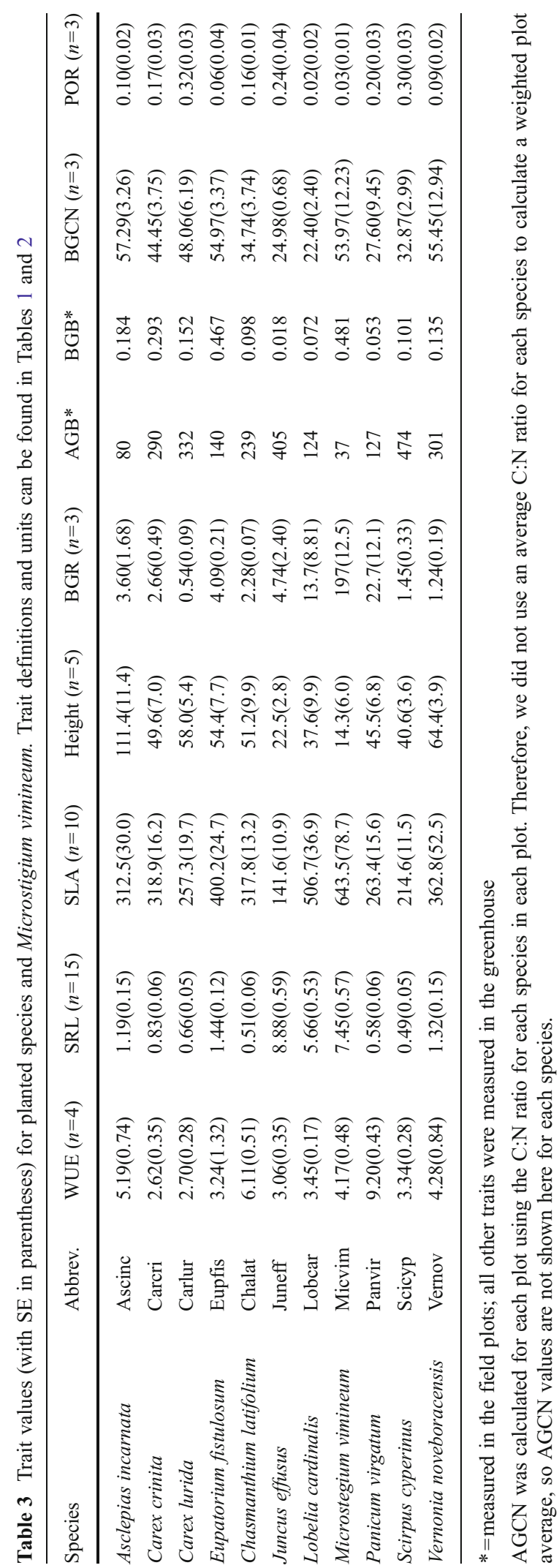


bulk density of each core (Culley 1993). A sub-sample of this dried soil was then used to determine percentage soil organic matter (OM) by loss on ignition (Patra et al.) at $450^{\circ} \mathrm{C}$ for four hours (Storer 1984). Two replicate $3 \mathrm{~g}$ field-moist sub-samples were analyzed for $2 \mathrm{M} \mathrm{KCl}$ extractable nitrate + nitrite $\left(\mathrm{NO}_{3}-\mathrm{N}\right)$ and ammonium $\left(\mathrm{NH}_{4}-\mathrm{N}\right)$ (Maynard and Kalra 1993) on a Lachat QuikChem 8000 (Lachat Instruments, Loveland, CO, USA.).

Denitrification Enzyme Assay (DEA) (Groffman et al. 1999; Smith and Tiedje 1979) was used as an index of denitrification potential (DNP). DEA measures potential denitrification because $\mathrm{C}$ and $\mathrm{N}$ are supplied in excess and the incubation is carried out under anaerobic conditions such that $\mathrm{N}_{2} \mathrm{O}$ gas produced is only a function of the level of enzyme in the sample. In this way, DEA is a useful technique to study maximum potential denitrification in ecosystems because enzyme concentration is correlated with long-term patterns of environmental conditions that control denitrification, such as soil moisture and C availability (Groffman et al. 1999). In the lab, duplicate samples of $5 \mathrm{~g}$ of homogenized, field-moist soil were amended with a solution of dextrose $(0.5 \mathrm{~g}$ per L) and $\mathrm{KNO}_{3}(0.72 \mathrm{~g}$ per $\mathrm{L})$ to ensure non-limiting substrate conditions and chloramphenicol $(0.125 \mathrm{~g}$ per $\mathrm{L})$ to inhibit protein synthesis. The slurries were made anaerobic with repeated flushing with $\mathrm{N}_{2}$ gas. Flasks $(125 \mathrm{~mL})$ were vented with a needle followed by an injection of $10 \mathrm{~mL}$ of acetylene into each flask to inhibit $\mathrm{N}_{2}$ production (Groffman et al. 1999; Smith and Tiedje 1979). Flasks were placed on an orbital shaker and shaken at $125 \mathrm{rpm}$ for $90 \mathrm{~min}$. Gas samples from the headspace of the flasks were collected at 30, 60 and 90 min with a syringe. Gas samples were stored in evacuated glass vials until analysis (max holding time $48 \mathrm{~h}$ ) on a Shimadzu GC-17A ${ }^{63} \mathrm{Ni}$ electron capture detector gas chromatograph (Shimadzu, Inc., Columbia, MD, USA.). $\mathrm{N}_{2} \mathrm{O}$ dissolved in sample water was corrected with the Bunsen equation (Moraghan and Buresh 1977). Linear rates of DNP were calculated based on the maximum activity measured during the incubation period.

\section{Aboveground plant biomass harvesting and lab analysis}

In September 2006 aboveground biomass in two $0.25 \mathrm{~m}^{2}$ quadrats was harvested and bulked from each plot. Species were sorted in the field into the 10 planted species, 'other,' or Microstegium vimineum (Japanese stiltgrass), an exotic grass that is common in riparian zones (Barden 1987) and is the only frequent invader of our experimental plots. All samples were dried at $60^{\circ} \mathrm{C}$ for a week and then weighed to determine total biomass for each species in each plot. A representative sub-sample of each species, based on a weighted allocation of stems, leaves, and reproductive structures, was then ground with a Wiley Mill or liquid $\mathrm{N}$ and then analyzed for total $\mathrm{N}$ using dry combustion on a FlashEA 1112 Elemental Analyzer (Thermo Scientific, Waltham, MA, USA.). The percent $\mathrm{N}$ of each species was then multiplied by the mass of that species in each plot to get $\mathrm{g}$ of $\mathrm{N}$ for that species; total biomass $\mathrm{N}$ was the sum of the $\mathrm{g}$ of $\mathrm{N}$ of each species in a plot.

\section{Trait measurements}

Ideally, we would have preferred to measure all traits on plants growing in the field, however, due to the destructive nature of some of the measurements, we were unable to measure all traits in the field without destroying our field plots, but for those traits where is was possible, we measured them in the field. Three traits, C:N ratio of aboveground biomass (AGCN), aboveground biomass (AGB), and belowground biomass (BGB), from our field plots (See above for details of the harvest). AGB was calculated for each species as the average aboveground biomass harvested in September 2006 from the two field monocultures of each species. The only exception to this was Lobelia cardinalis because monocultures of this species were severely impacted by deer herbivory in 2006. Instead, we substituted similar measurements taken in 2005 on a different set of plots at the same site that also included $L$. cardinalis monocultures but that were less heavily deer-browsed. BGB was similarly calculated as the average total root biomass from the August 2006 soil from the two monocultures of each species with two exceptions. We used root biomass from the same plots of L. cardinalis from 2005 that we used for biomass estimates. Because we did not have any monocultures of $M$. vimineum, we used the root biomass from an adjacent unplanted control plot with naturally recruited $M$. vimineum accounting for $63 \%$ of the plot aboveground biomass.

We measured the remaining plant traits on individuals of the same species grown in the greenhouse under greenhouse conditions designed to replicate temperature, humidity, and photoperiod at the field site. Individuals of each species were started from seed 
and then transplanted to individual pots as seedlings and grown in a normal greenhouse potting mix (Metromix). Species were then grown in pots for two months and kept at a constant water level with saturation at $15 \mathrm{~cm}$ below the surface which approximates average field water table depth. Species traits were measured in June 2005. All traits were continuous variables. We measured photosynthesis and transpiration at $1000 \mu \mathrm{mol} \mathrm{sec} \mathrm{m}^{-1}$ and at ambient levels of $\mathrm{CO}_{2}$ to calculate water use efficiency (WUE) using a LiCor-6400 (LI-COR Biosciences, Lincoln, Nebraska, USA) (Diaz 2001). We estimated root length using WinRhizo software to calculate specific root length (SRL, $\mathrm{cm} \mathrm{g}^{-1}$ ) (Cornelissen et al. 2003). We also measured specific leaf area (SLA, $\mathrm{cm}^{2} \mathrm{~g}^{-1}$ ) (Cornelissen et al. 2003), plant height, and belowground biomass distribution (BGR), the ratio of root biomass above the water table (which was fixed at $15 \mathrm{~cm}$ below the surface in our greenhouse treatments) to root biomass below the water table. $\mathrm{C}: \mathrm{N}$ ratio of belowground biomass (BGCN) was measured on a FlashEA 1112 Elemental Analyzer (Thermo Scientific, Waltham, MA, USA.), and root porosity (POR) was measured using the pycnometer method (Jensen et al. 1969).

For WUE, SLA, Height, and AGCN, average trait values for each plot were calculated by multiplying the trait value for each species by the weighted average of the aboveground biomass of each species in the plot. SRL, BGR, and BGCN weighted averages for each plot were calculated based on belowground biomass estimates as calculated using the aboveground biomass from the field and the root:shoot ratio from our greenhouse harvest.

\section{Statistical analyses}

Because we measured denitrification potential in the same plots throughout the growing season, we verified that our residuals from each sampling date were independent and normally distributed. The median value and spread of the residuals from each sampling month were very similar (data not shown). QQ plots also confirmed that residuals from each month did not differ greatly from those in the overall data. This analysis confirmed that there was no obvious monthto-month shift in terms of model performance. As a result, we combined all dates into one dataset that represents the denitrification potential in the second growing season. Because we only sampled biomass $\mathrm{N}$ once in September, the soils data used in the biomass $\mathrm{N}$ analysis was an average of the soils variables collected throughout the growing season in each plot. These analyses were performed using the software package R 2.4.1 (R Development Core Team 2008).

We used structural equation models (SEM) to examine the influence of plant traits and environmental factors on biomass $\mathrm{N}$ and denitrification potential. Prior to performing the SEM analysis, some variables were log transformed to better conform to assumptions of normality and linearity (Grace 2006). We also checked for multivariate outliers using Mahalanobis distance in the software package Amos 5.0.1 (Arbuckle 1995). Based on this analysis we removed three outliers from the biomass $\mathrm{N}$ data and two from the denitrification data. Next we confirmed that our data met the assumptions of multivariate kurtosis and normality using the critical ratio (C.R. $<5$ means data are multivariate normal (Byrne 2010)). After determining that our construct model was significant and therefore not a good representation of the structure in the data, following standard SEM protocols we modified our model based on the modification indices suggested by AMOS (Arbuckle 1995) in order to develop a non-significant model for biomass $\mathrm{N}$ and denitrification potential (note that in SEM, the significance test indicates whether the proposed model structure and the structure of the data are significantly different, thus a significant model is one that does not adequately explain the underlying structure in the data) (Arbuckle 1995). Standardized coefficients are presented in the results to facilitate the comparison of the relative strengths of the relationships between the predictor and response variables.

Based on the results of our SEM analysis, we also performed a non-metric multidimensional scaling (NMS) ordination using the important traits from the SEM models to examine the relationships between different species in trait space. Prior to the ordination, data were transformed to z-scores so that all variables would have equal weight in the analysis and then we used a Euclidean distance metric. Analysis was performed in the statistics package PCOrd 4.41 (McCune and Mefford 1999).

\section{Results}

Plant traits

Traits measurements for all species for both the biomass $\mathrm{N}$ and DNP models are shown in Table 3. The range in values for each trait demonstrate that our 
efforts to select species expressing a variety of trait values were reasonably successful. Trait values tended to vary by at least a factor of 2.5 across all eleven species, as is the case for BGCN, and up to about a factor of 10 for SRL and POR.

\section{Biomass nitrogen results}

Once we revised the construct model based on the modification indices, the biomass $\mathrm{N}$ model had good fit (chi-square $p$-value $=0.848, \mathrm{CFI}=1.0, \mathrm{TLI}=1.08$, RMSEA $=0.0$, Hoelter $=238$ ). The two significant predictors of biomass $\mathrm{N}$ were soil $\mathrm{N}$ (positive relationship) and WUE (negative relationship) (Fig. 2a). Both variables have similar coefficients meaning that the environmental variable and the plant trait variable are equally important predictors of biomass N. In terms of the correlations between the explanatory variables, soil $\mathrm{N}$ and soil $\mathrm{OM}$ were positively correlated, and plant height and BGR were negatively correlated. Bivariate relationships between traits, environmental factors, and biomass $\mathrm{N}$ also support these significant relationships in the SEM model (Figure S1 in supplemental material). Interestingly, there was also a significant negative correlation between soil OM and WUE.

\section{Denitrification potential results}

Average, minimum and maximum site DNP values can be found in Appendix A. The revised model for DNP also had good fit (chi-square p-value $=0.614$, $\mathrm{CFI}=1.0, \mathrm{TLI}=1.02$, RMSEA $=0.0$, Hoelter $=521$ ). The significant predictors of DNP were soil N (positive relationship), soil OM (positive relationship), BGB (positive relationship) and POR (negative relationship) (Fig. 2b). In general the plant traits were weaker predictors of DNP than the environmental factors. BGCN and AGB were marginally significant ( $p$-values $=0.067$ and 0.066 , respectively) with $\mathrm{BGCN}$ demonstrating a negative relationship and AGB a positive relationship with DNP. There were also many significant correlations between the explanatory variables. Both soil properties were positively correlated, and two plant traits, BGCN and POR, were negatively correlated. In addition to these relationships, soil $\mathrm{N}$ and soil $\mathrm{OM}$ were both positively correlated with $\mathrm{AGB}$, soil OM was positively correlated with $\mathrm{BGB}$, and soil $\mathrm{N}$ was negatively correlated with BGCN. The significant relationships in the SEM model are also supported by the bivariate a

\section{Biomass N Model}

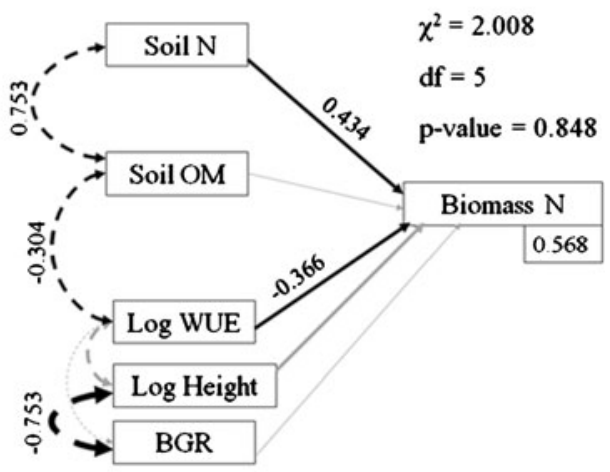

b

\section{Denitrification Potential Model}

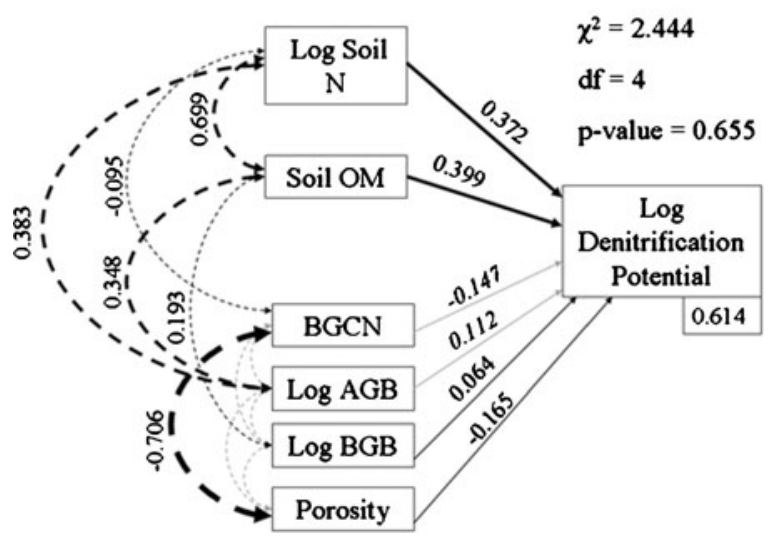

Fig. 2 Model results for (a) biomass $\mathrm{N}$ and (b) denitrification potential (DNP). The significant parameters $(p$-value $\leq 0.05)$ in each model are in bold and have path coefficients while the nonsignificant parameters are gray without path coefficients. The two exceptions to this are the paths from BGCN and LogAGB to DNP which had $p$-values $=0.07$, so their coefficients are listed but italicized. Both models have good fit as shown by the nonsignificant $\chi^{2}$ (Chi-squared test statistic) and model p-value; $\mathrm{p}$ values $>0.05$ indicate the model structure and the data structure do not differ. Direct paths are solid, straight lines while correlations are curved, dashed lines. Path coefficients are standardized. The width of the arrows indicates each parameter's relative importance with thicker lines being parameters with a greater influence. The models explained $56.8 \%$ of the variability in biomass $\mathrm{N}$ and $61.4 \%$ of the variability in DNP

relationships between traits, environmental factors, and DNP (Figure S2 in supplemental material).

\section{NMS results}

The three NMS axes accounted for $96.1 \%$ of the variability in species traits. Axis 1 explained $22.4 \%$ 
of the variability and was characterized by a negative relationship with WUE and a positive relationship with AGB (Fig. 3). Axis 2 was characterized by negative relationships with $\mathrm{BGR}, \mathrm{BGB}$, and $\mathrm{BGCN}$, and a positive relationship with $\mathrm{POR}$, and accounted for $57.3 \%$ of the variability.

The members of the related sedge (CyperaceaeCarex crinita, Carex lurida, and Scirpus cyperinus) and rush (Juncaceae-Juncus effusus) families generally clustered together in trait space on Axes 1 and 2. The other species did not cluster based on life form or any other kind of taxonomic grouping that we perceived.

Based on the relationships between the plant traits and ecosystem functions, increases in each function are related to specific regions of trait space. For example, biomass $\mathrm{N}$ was negatively

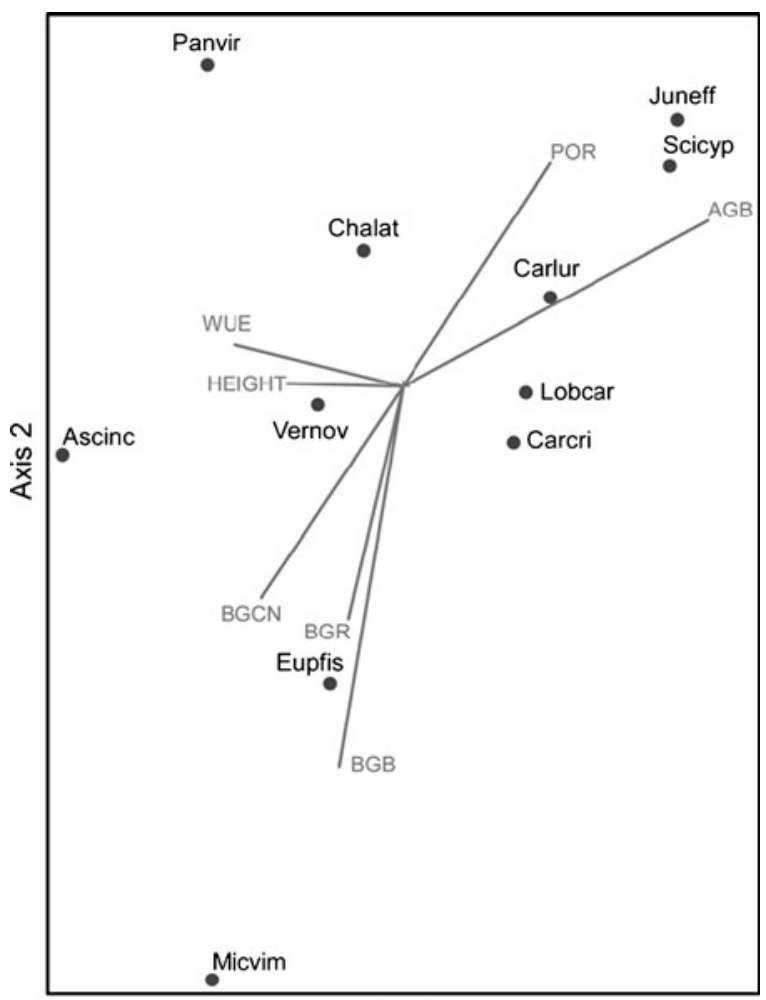

Axis 1

Fig. 3 Non-metric multidimensional (NMS) ordination of the species in trait space. Species abbreviations are as listed in Table 3. Traits used in the ordination were those in the revised SEM models for both biomass N and DNP. Traits displayed are those with loadings $>0.2$ on each axis. Axis 1 accounted for $22.4 \%$ of the variation and Axis 2 accounted for $57.3 \%$. The NMS ordination with all three axes (third axis not shown) explained $96.1 \%$ of the variability in species correlated with WUE, which is roughly in the same area of trait space as species with traits similar to the sedges and rushes (the middle, right side of Fig. 3). DNP, on the other hand, was negatively correlated with POR and positively correlated with BGB suggesting that DNP can be maximized by species with traits similar to E. fistulosum (bottom, left corner of Fig. 3). However, if we account for the two other traits, BGCN and AGB, which were marginally significantly related to DNP, BGCN was negatively correlated to DNP and AGB was positively correlated. These traits indicate that DNP is maximized in the opposite part of trait space (upper, right corner of Fig. 3). These results suggest that no single position in trait space could maximize all trait values that were correlated with an increase in DNP. Furthermore, the traits that maximize biomass $\mathrm{N}$ are not in the same region of trait space as those that maximize DNP and do not overlap with the same species; these results indicate that the same species do not maximize both ecosystem functions.

\section{Discussion}

A number of studies suggest that plant traits influence ecosystem functioning (see, for example, Diaz and Cabido 1997; Diaz et al. 2004). We determined that plant traits significantly influenced both $\mathrm{N}$ removal ecosystem functions, biomass $\mathrm{N}$ and DNP, and in the case of biomass $\mathrm{N}$ were of approximately equal importance to environmental variables. However, many generally accepted trait relationships were not supported suggesting that the standard models of plantsoil relationships need to be critically evaluated.

Which specific traits and environmental factors control biomass $\mathrm{N}$ ?

Four of our five biomass $\mathrm{N}$ plant traits were not important predictors of biomass N. Neither the traits that represent resource acquisition (SLA and SRL) nor the architectural growth traits (Height and Belowground Rooting ratio) had significant relationships with biomass $\mathrm{N}$. This was unexpected given that many studies have demonstrated a tight relationship between plant traits representing resource acquisition and plant growth architecture at both regional and global scales (Craine et 
al. 2002; Kerkhoff et al. 2005; Reich et al. 1992). We only found one trait, WUE, that substantially influenced biomass N (Fig. 2). WUE was negatively correlated with biomass $\mathrm{N}$ which is possibly due to the fact that plants with higher WUE take up less moisture from the soil and therefore may also take up less available $\mathrm{N}$ from the soil therefore having lower biomass $\mathrm{N}$. This is the opposite pattern from that found in Steers et al. (2011) who determined that plants in arid and semi-arid environments with high WUE often require large amounts of Rubisco and therefore have high leaf $\mathrm{N}$.

Even though our hypothesized relationships between plant traits and biomass $\mathrm{N}$ were based on fundamental assumptions about which plant traits are related to productivity (Cornelissen et al. 2003; Diaz and Cabido 1997), only one of our five plant traits was a significant predictor of biomass $\mathrm{N}$; this means the basic models about how plant traits relate to productivity do not hold up well in this case. It is possible that we do not see the predicted relationships within this wetland ecosystem because the range of traits is small whereas at cross-ecosystem scales, where the range in variation in traits is presumably larger, predicted relationships may be stronger. Another possibility is that we did not measure the traits 'well,' meaning we did not get accurate measurements of our traits. This is possible given some of the traits were measured on plants grown in the greenhouse and these trait values may not correspond as tightly to traits expressed in the field even though we designed our greenhouse study to replicate field conditions as closely as possible. Still there were likely uncontrollable differences between greenhouse and field conditions, including storm events, the potential influence of neighboring plants, as well as other biological interactions such as with pollinators or pests, which could influence plant trait expression. We know that phenotypic plasticity of plant traits can occur and that trait plasticity can be influenced by several abiotic and biotic factors including nutrient and water availability, or the presence, absence, density, or identity of neighbors (See R. M. Callaway et al. (2003b) for a good review of these studies). But, although it is generally assumed that plant traits are plastic, we do not fully understand the consequences of phenotypic plasticity on plant fitness, the interactions among plants, or on plant community dynamics (Callaway et al. 2003b). As a result, an important future research direction includes determining what conditions are most likely to influence phenotypic plasticity; this will inform our understanding of how plant traits influence community dynamics including how biodiversity impacts ecosystem function. Nonetheless, our results suggest that our understanding of how traits impact ecosystem functions is very likely incomplete and that we need more data to develop a mechanistic understanding about how specific plant traits contribute to ecosystem function.

In terms of the environmental variables, as we hypothesized soil $\mathrm{N}$ was significantly related to biomass N. However, soil OM was not a significant predictor of biomass $\mathrm{N}$ even though soil $\mathrm{OM}$ can be an important source of nutrients for plant growth (Brady and Weil 1999; Wardle et al. 2004), suggesting that over the relatively short timeframe of this experiment, plant nutrient uptake was likely not controlled by rates of soil $\mathrm{OM}$ decomposition.

Which specific traits and environmental factors influence denitrification potential?

Plants indirectly affect denitrification by changing the soil environment in which the denitrifying microbes live. It is well established that plants affect soil environment structure through several mechanisms including the release of cementing materials, the creation of pore spaces, and the addition of litter and humus (Wardle 2002). Some studies have found plant traits are key determinants of soil ecosystem properties and processes such as total $\mathrm{N}$ and microbial biomass and activity (Bardgett et al. 1999; Wardle et al. 1998). Additionally, many studies have found plant species effects on several microbiallydriven soil processes such as $\mathrm{N}$ mineralization, nitrification, $\mathrm{CH}_{4}$ and $\mathrm{CO}_{2}$ release (Hobbie 1992; Knops et al. 2002; Steltzer and Bowman 1998; Sutton-Grier and Megonigal 2011; Verville et al. 1998; Wedin and Tilman 1990) as well as denitrification (Hernandez and Mitsch 2007; Hume et al. 2002; Lin et al. 2002; Patra et al. 2006; Pinay et al. 2007). These plant-induced changes are mainly due to differences in the quality of plant inputs to soils, which is determined by the ecological strategies and the associated suite of traits of the dominant species (Wardle 2002). Thus, as predicted, we found significant relationships between two plant traits, belowground biomass (BGB) and root porosity (POR), and denitrification potential (Fig. 2). We also found two marginally significant $(p$-value $=0.07$ ) relationships between aboveground biomass (AGB) and belowground biomass $\mathrm{C}: \mathrm{N}(\mathrm{BGCN})$ and denitrification potential. 
The positive relationship between below-ground biomass and denitrification potential is as predicted, and likely reflects increased carbon supply for denitrifiers. Both of the marginally significant relationships, aboveground biomass and belowground biomass $\mathrm{C}: \mathrm{N}$, were in the direction that we predicted as well suggesting that as carbon quantity and quality increase so does denitrification potential. However, we cannot explain the negative relationship between root porosity and denitrification potential. We hypothesized that plants with high root porosity might aerate rhizospheres, and these oxygen inputs, under saturated soil conditions, would stimulate nitrifying bacteria to transform ammonia to nitrate providing a source of nitrate for denitrifying bacteria (Cronk and Fennessy 2001). However, in our riparian wetland study site, we found that soil water levels were never high enough at any of our sampling dates in the peak summer season to saturate the top $15 \mathrm{~cm}$ of the soil profile. We measured potential denitrification in the lab, which does not represent the rate of denitrification occurring in the field, but instead represents what the community of denitrifiers is capable of under ideal conditions. But, unlike our prediction, we did not find that soils from plots where plants had greater root porosity had higher potential denitrification, but instead had lower potential denitrification. Thus, this negative relationship is puzzling. Perhaps root porosity correlates with another unmeasured plant trait that causes a decrease in denitrification potential.

In addition to the plant traits, we found both soil factors were significantly related to denitrification potential. Soil $\mathrm{N}$ availability and $\mathrm{N}$ inputs have strong positive effects on potential denitrification (Ettema et al. 1999; Groffman 1994; Lowrance and Hubbard 2001). Soil $\mathrm{C}$ controls variation in denitrification at some sites, as C supply is the ultimate regulator of microbial activity and population size, including denitrifiers (Drury et al. 1991; Groffman 1994; Groffman and Crawford 2003; Sutton-Grier et al. 2009). These results suggest that the availability of both soil $\mathrm{N}$ and soil C may limit denitrification at this site.

The relative importance of traits versus environmental factors

It is noteworthy that both soil $\mathrm{N}$ and WUE have roughly equal standardized effects on biomass $\mathrm{N}$ (0.434, and -0.366 , respectively) (Fig. 2a). Based on this analysis, this suggests that environmental factors have approximately the same relative importance as plant traits in controlling biomass N. For denitrification potential, however, both environmental factors, soil $\mathrm{N}$ and soil $\mathrm{OM}$, have strong standardized path coefficients ( 0.372 and 0.399 , respectively) while the two significant trait predictors have much smaller standardized path coefficients (belowground biomass $=0.064$ and root porosity $=-0.165$ ) . Our results are consistent with the generalization that plants influence microbial activity largely by modifying the environmental conditions that the microbes experience. Several plant traits were correlated with the soil variables, and AGB and BGCN were correlated with soil $\mathrm{OM}$ and/or soil $\mathrm{N}$ but did not have a significant direct effect on DNP. Thus, plant traits were more likely to impact denitrification by influencing the environment the microbes experienced.

\section{Environment and trait correlations}

In our original construct models (Fig. 1a and b) we did not propose any correlations between the environmental variables and the plant traits for two primary reasons. First, many plant traits were measured in the greenhouse under constant environmental conditions and therefore we did not hypothesize specific relationships with environmental variability of soils in the field and measured plant traits. Second, a correlation between a plant trait, such as root porosity, and a soil variable, such as soil moisture, would not imply that the trait was changing in response to the environment (i.e., trait plasticity); trait plasticity could have been occurring at our field site, but our model was not designed to test the plasticity of plant traits with environmental variability. Instead, a correlation in our model would suggest that certain environmental conditions favored certain plant trait values. In other words, even though we planted all species with equal abundance initially, the environmental conditions in the field may have favored the growth of species with particular traits leading to correlations between environmental variables and specific plant traits.

Based on the modification indices, there were some significant correlations in the data between the soils variables and some of the plant traits that we included in our revised models. For example, in the biomass $\mathrm{N}$ model soil OM was negatively correlated with WUE (Fig. 2a). Although we did not originally propose this 
relationship, it does make intuitive sense. Soils with more soil OM will be able to hold more water which would mean that plants would not need to be as water efficient to survive in those plots. This suggests that the environmental conditions in the field may have selected for species that were more or less water efficient depending on the soil OM levels in a plot resulting in average trait values for WUE that decreased as soil OM levels increased.

For denitrification potential, the most interesting significant correlation between environmental factors and plant traits was the negative relationship between soil $\mathrm{N}$ and belowground $\mathrm{C}: \mathrm{N}$ suggesting that as soil resources increase, the $\mathrm{C}: \mathrm{N}$ ratio of belowground tissues decreases likely because the plants are able to take up more $\mathrm{N}$ from the soil. This correlation between soil $\mathrm{N}$ and average belowground $\mathrm{C}: \mathrm{N}$ suggests that field conditions may have influenced which species were most productive under different environmental conditions leading to lower average belowground $\mathrm{C}: \mathrm{N}$ values in plots with higher soil $\mathrm{N}$.

Relationship of species, traits, and ecosystem functions

It is interesting to note that by combining our understanding of the plant traits that significantly influence each ecosystem function with our ordination results, we can determine that supporting both N-removing ecosystem functions likely requires different species; no single species has combinations of trait values that promote both functions. Examining the ordination results, we determined that the biomass $\mathrm{N}$ traits and the denitrification traits do not substantially overlap in trait space (Fig. 3). WUE, the only significant plant trait to predict biomass $\mathrm{N}$, loads negatively on Axis 1 . The important traits for predicting denitrification potential, $\mathrm{BGB}$ and $\mathrm{POR}$, are relatively orthogonal to WUE since they load more strongly on Axis 2 . These results suggest that different trait values are needed to support high levels of each ecosystem function. Because different species overlap with the traits that maximize each function, a variety of species are likely needed to maximize both functions. Thus, despite the fact that our two N-removing ecosystem functions are related to some degree because overall plant productivity is related to plant inputs to the soil microbial community, the same plant species do not seem to promote both ecosystem functions.
Our results are consistent with other studies that have suggested that more diverse communities are needed in order to support multiple ecosystem functions simultaneously (Gamfeldt et al. 2008; Hector and Bagchi 2007), particularly through time and under changing environmental conditions (Duffy 2009). Two additional studies at this field site determined that plant trait diversity, or functional diversity (FD), influenced DNP. McGill et al. (2010) determined that increased FD decreased the variability of DNP through time. Sutton-Grier et al. (2011) found that increased FD led to increased DNP mainly at higher levels of soil resources. This current study suggests that individual plant traits influence ecosystem processes and that the traits that influence biomass $\mathrm{N}$ are not strongly correlated with the traits that influence denitrification potential. These results suggest that to support multiple ecosystem functions, a diversity of species with different traits are important.

Our results provide a more mechanistic understanding of multi-functionality by explicitly incorporating information on plant traits. While we do not want to extrapolate too far beyond the nature of this particular study, one of the advantages of using plant traits is that we can generalize the trait results beyond the eleven species used in this experiment. Assuming ecologically or taxonomically similar plants have a similar range of traits at other study sites and in other wetland communities, we can generalize the relationships between traits and ecosystem functions we determined in this study to other communities. But we see a real need for further research that mechanistically links specific plant traits to ecosystem functions. Additional traitbased ecology research promises to link quantitative variables to functional relationships in ecosystems, improving both the identification of general ecological patterns, but also our ability to predict and manage ecosystem responses to disturbance and global climate change (Eviner and Chapin 2003; McGill et al. 2006; Westoby and Wright 2006). Currently trait-based ecology is limited by a need for more development of trait databases for species around the world. Trait measurements are often labor intensive and expensive and therefore are frequently not included in the design of ecological studies. But a better understanding of how species traits vary within a population and across geographic gradients is key to developing a more mechanistic understanding of how multi-species communities function. 


\section{Conclusions}

The results of this study demonstrate that plant traits influence riparian $\mathrm{N}$ removal via both plant biomass $\mathrm{N}$ and denitrification, the two primary ecosystem functions that temporarily or permanently remove $\mathrm{N}$ from wetland soils. The ecological implications of these results are especially important for restored systems since, based on our results, the selection of plant species can be critical to establishing ecosystems capable of performing multiple ecosystem functions. Given that biomass $\mathrm{N}$ was maximized by a trait that did not covary with the traits leading to high denitrification potential, it is unlikely that the same plants can maximize both ecosystem functions. Here we considered only two ecosystem functions. Trait diversity is likely to be even more important when an entire suite of ecosystem functions are desired from a restored system. Therefore, to maximize multiple ecosystem functions simultaneously, a diverse set of plants will likely be needed to ensure that the appropriate conditions are present for each function.

Acknowledgments We especially wish to thank Eileen Thorsos for very helpful discussion of hypotheses and data analysis, and Jennifer Funk for comments on the manuscript. We would like to thank Paul Heine, Wes Willis, Joseph Lozier, Tracy Hamm, Amanda Ward, Sarah Eminhizer, Nate Emery, Josie Bamford, Serwaah Agyapong, Aileen Malloy, Lauren Kinsman, Amy Hammontree, Erin Brosnan, Doug Gorecki, Jocelyn Tutak, Youngeun Cho, Ahmed Farawi, and Tisha Johnson for help with sample processing. We also thank the many people who helped us with field work: Dr. Mengchi Ho, Dr. James Pahl, Mike Osland, Jen Morse, Julie DeMeester, Amani McHugh, Arlene Mendoza, Joseph Sexton, Eileen Thorsos, Dawoon Jung, and Nancy Morgans. This work was supported by NSF Grant DEB0508763, an NSF Graduate Research Fellowship, an American Fellowship from the Association of University Women Educational Foundation to A.E.S., a Society of Wetland Scientist Student Research Grant, the Duke Wetlands Center Case Study Endowment, and a grant from the USDA Natural Resources Conservation Service. A. E. S. was also partially supported by a Smithsonian Fellowship from the Smithsonian Environmental Research Center.

\section{References}

Arbuckle JL 1995 Amos User's Guide 7.0. Amos Development Corporation, Spring House, PA.

Balvanera P, Pfisterer AB, Buchmann N, He JS, Nakashizuka T, Raffaelli D, Schmid B (2006) Quantifying the evidence for biodiversity effects on ecosystem functioning and services. Ecol Lett 9:1146-1156
Barden LS (1987) Invasion of Microstegium-Vimineum (Poaceae), an Exotic, Annual, Shade-Tolerant, C-4 Grass, into a North-Carolina Floodplain. Am Midl Nat 118:40-45

Bardgett RD, Mawdsley JL, Edwards S, Hobbs PJ, Rodwell JS, Davies WJ (1999) Plant species and nitrogen effects on soil biological properties of temperate upland grasslands. Funct Ecol 13:650-660

Brady NC, Weil RR (1999) The Nature and Properties of Soils. Prentice Hall, Upper Saddle River, NJ

Burke IC, Lauenroth WK, Vinton MA, Hook PB, Kelly RH, Epstein HE, Aguiar MR, Robles MD, Aguilera MO, Murphy KL, Gill RA (1998) Plant-soil interactions in temperate grasslands. Biogeochemistry 42:121-143

Byrne B M 2010 Structural Equation Modeling with AMOS: Basic concepts, applications, and programming. Routledge, New York, NY, U.S.A.

Callaway JC, Sullivan G, Zedler JB (2003a) Species-Rich Plantings Increase biomass and Nitrogen Accumulation in a Wetland Restoration Experiment. Ecol Appl 13:1626-1639

Callaway RM, Pennings SC, Richards CL (2003b) Phenotypic plasticity and interactions among plants. Ecology 84:11151128

Cardinale BJ, Srivastava DS, Duffy JE, Wright JP, Downing AL, Sankaran M, Jouseau C (2006) Effects of biodiversity on the functioning of trophic groups and ecosystems. Nature 443:989-992

Cavigelli MA, Robertson GP (2000) The functional significance of denitrifier community composition in a terrestrial ecosystem. Ecology 81:1402-1414

Cavigelli MA, Robertson GP (2001) Role of denitrifier diversity in rates of nitrous oxide consumption in a terrestrial ecosystem. Soil Biol Biochem 33:297-310

Chapin FS (2003) Effects of plant traits on ecosystem and regional processes: a conceptual framework for predicting the consequences of global change. Ann Bot 91:455-463

Chapin FS III, Reynolds HL, D'Antonio CM, Eckhart VM (1996) The functional role of species in terrestrial ecosystems. In: Walker B, Steffan W (eds) Global Change and Terrestrial Ecosystems. Cambridge University Press, Cambridge, U.K, pp 403-428

Chapin FS, Zavaleta ES, Eviner VT, Naylor RL, Vitousek PM, Reynolds HL, Hooper DU, Lavorel S, Sala OE, Hobbie SE, Mack MC, Diaz S (2000) Consequences of changing biodiversity. Nature 405:234-242

Cornelissen JHC, Lavorel S, Garnier E, Diaz S, Buchmann N, Gurvich DE, Reich PB, ter Steege H, Morgan HD, van der Heijden MGA, Pausas JG, Poorter H (2003) A handbook of protocols for standardised and easy measurement of plant functional traits worldwide. Aust J Bot 51:335-380

Cornwell WK, Cornelissen JHC, Amatangelo K, Dorrepaal E, Eviner VT, Godoy O, Hobbie SE, Hoorens B, Kurokawa H, Perez-Harguindeguy N, Quested HM, Santiago LS, Wardle DA, Wright IJ, Aerts R, Allison SD, van Bodegom P, Brovkin V, Chatain A, Callaghan TV, Diaz S, Garnier E, Gurvich DE, Kazakou E, Klein JA, Read J, Reich PB, Soudzilovskaia NA, Vaieretti MV, Westoby M (2008) Plant species traits are the predominant control on litter decomposition rates within biomes worldwide. Ecol Lett 11:1065-1071

Craine JM, Tilman D, Wedin D, Reich P, Tjoelker M, Knops J (2002) Functional traits, productivity and effects on nitrogen cycling of 33 grassland species. Funct Ecol 16:563-574 
Cronk JK and Fennessy MS 2001 Adaptations to Growth Conditions in Wetlands. In Wetland Plants: Biology and Ecology. pp 87-145. Lewis Publishers, Boca Raton.

Crush JR (1998) Effect of different forage plants on denitrification potential of Horotiu soil. N Z J Agric Res 41:421-426

Culley JLB (1993) Density and Compressibility. In: Carter MR (ed) Soil sampling and methods of analysis. Lewis Publishers, Boca Raton, FL, pp 529-539

Diaz S (2001) Ecosystem Function, Measurement, Terrestrial communities. In: Levin SA (ed) Encyclopedia of Biodiversity. Academic, San Diego, pp 321-344

Diaz S, Cabido M (1997) Plant functional types and ecosystem function in relation to global change. J Veg Sci 8:463-474

Diaz S, Hodgson JG, Thompson K, Cabido M, Cornelissen JHC, Jalili A, Montserrat-Marti G, Grime JP, Zarrinkamar F, Asri Y, Band SR, Basconcelo S, Castro-Diez P, Funes G, Hamzehee B, Khoshnevi M, Perez-Harguindeguy N, Perez-Rontome MC, Shirvany FA, Vendramini F, Yazdani S, Abbas-Azimi R, Bogaard A, Boustani S, Charles M, Dehghan M, de Torres-Espuny L, Falczuk V, GuerreroCampo J, Hynd A, Jones G, Kowsary E, Kazemi-Saeed F, Maestro-Martinez M, Romo-Diez A, Shaw S, Siavash B, Villar-Salvador P, Zak MR (2004) The plant traits that drive ecosystems: Evidence from three continents. J Veg Sci 15:295-304

Drury CF, McKenney DJ, Findlay WI (1991) Relationships between Denitrification, Microbial Biomass and Indigenous Soil Properties. Soil Biol Biochem 23:751-755

Duffy JE (2009) Why biodiversity is important to the functioning of real-world ecosystems. Front Ecol Environ 7:437-444

Dukes JS (2000) Will the increasing atmospheric CO2 concentration affect the success of invasive species? In: Mooney HA, Hobbs RJ (eds) In Invasive species in a changing world. Island Press, Washington, D.C, pp 95-113

Ehrenfeld JG, Ravit B, Elgersma K (2005) Feedback in the plant-soil system. Annu Rev Environ Res 30:75-115

Engelhardt KA, Ritchie ME (2001) Effects of macrophyte species richness on wetland ecosystem functioning and services. Nature 411:687-689

Ettema CH, Lowrance R, Coleman DC (1999) Riparian soil response to surface nitrogen input: temporal changes in denitrification, labile and microbial $\mathrm{C}$ and $\mathrm{N}$ pools, and bacterial and fungal respiration. Soil Biol Biochem 31: $1609-1624$

Eviner VT (2004) Plant traits that influence ecosystem processes vary independently among species. Ecology 85:2215-2229

Eviner VT, Chapin FS (2003) Functional matrix: A conceptual framework for predicting multiple plant effects on ecosystem processes. Annu Rev Ecol Evol Syst 34:455-485

Farrar J, Hawes M, Jones D, Lindow S (2003) How roots control the flux of carbon to the rhizosphere. Ecology 84:827-837

Fornara DA, Tilman D (2008) Plant functional composition influences rates of soil carbon and nitrogen accumulation. J Ecol 96:314-322

Fornara DA, Tilman D, Hobbie SE (2009) Linkages between plant functional composition, fine root processes and potential soil N mineralization rates. J Ecol 97:48-56

Gamfeldt L, Hillebrand H, Jonsson PR (2008) Multiple functions increase the importance of biodiversity for overall ecosystem functioning. Ecology 89:1223-1231
Grace JB (2006) Structural Equation Modeling and Natural Systems. Cambridge University Press, Cambridge

Grime JP (1998) Benefits of plant diversity to ecosystems: immediate, filter and founder effects. J Ecol 86:902-910

Groffman PM (1987) Nitrification and denitrification in soil - A comparison of enzyme assay, incubation and enumeration methods. Plant Soil 97:445-450

Groffman PM (1994) Denitrification in Freshwater Wetlands. Curr Topics Wetland Biogeochem 1:15-35

Groffman PM, Crawford MK (2003) Denitrification potential in urban riparian zones. J Environ Qual 32:1144-1149

Groffman PM, Axelrod EA, Lemunyon JL, Sullivan WM (1991) Denitrification in grass and forest vegetated filter strips. J Environ Qual 20:671-674

Groffman PN, Holland EA, Myrold DD, Robertson GP, Zou X (1999) Denitrification. In: Robertson GP, Coleman DC, Bledsoe CS, Sollins P (eds) Standard Soil Methods for Long-Term Ecological Research. Oxford University Press, Oxford, U.K, pp 272-288

Hall K 2003 Recommended Native Plant Species for Stream Restoration in North Carolina. North Carolina Stream Restoration Institute, North Carolina State University, Raleigh.

Hector A, Bagchi R (2007) Biodiversity and ecosystem multifunctionality. Nature 448:188-191

Hector A, Schmid B, Beierkuhnlein C, Caldeira MC, Diemer M, Dimitrakopoulos PG, Finn JA, Freitas H, Giller PS, Good J, Harris R, Hogberg P, Huss-Danell K, Joshi J, Jumpponen A, Korner C, Leadley PW, Loreau M, Minns A, Mulder CPH, O’Donovan G, Otway SJ, Pereira JS, Prinz A, Read DJ, Scherer-Lorenzen M, Schulze ED, Siamantziouras ASD, Spehn EM, Terry AC, Troumbis AY, Woodward FI, Yachi S, Lawton JH (1999) Plant diversity and productivity experiments in European grasslands. Science 286:11231127

Hernandez ME, Mitsch WJ (2007) Denitrification potential and organic matter as affected by vegetation community, wetland age, and plant introduction in created wetlands. J Environ Qual 36:333-342

Hill AR (1996) Nitrate removal in stream riparian zones. J Environ Qual 25:743-755

Hill AR, Cardaci M (2004) Denitrification and organic carbon availability in riparian wetland soils and subsurface sediments. Soil Sci Soc Am J 68:320-325

Hobbie SE (1992) Effects of Plant-Species on Nutrient Cycling. Trends Ecol Evol 7:336-339

Hooper DU, Vitousek PM (1997) The effects of plant composition and diversity on ecosystem processes. Science 277 : 1302-1305

Hooper DU, Chapin FS, Ewel JJ, Hector A, Inchausti P, Lavorel S, Lawton JH, Lodge DM, Loreau M, Naeem S, Schmid B, Setala H, Symstad AJ, Vandermeer J, Wardle DA (2005) Effects of biodiversity on ecosystem functioning: A consensus of current knowledge. Ecol Monogr 75:3-35

Houghton JT, Ding Y, Griggs DJ, Noguer M, van der Linden PJ, Dai X, Maskell K, Johnson CA (2001) Technical Summary. In: Houghton JT, Ding Y, Griggs DJ, Noguer M, van der Linden PJ, Dai X, Maskell K, Johnson CA (eds) Climate Change 2001: the Scientific Basis. Contribution of Working Group I to the Third Assessment Report of the Intergovernmental Panel on Climate Change. Cambridge University Press, Cambridge, pp 22-83 
Hume NP, Fleming MS, Horne AJ (2002) Denitrification potential and carbon quality of four aquatic plants in wetland microcosms. Soil Sci Soc Am J 66:1706-1712

Jensen CR, Luxmoore RJ, Vangundy SD, Stolzy LH (1969) Root Air Space Measurements by a Pycnometer Method. Agron J 61:474

Kerkhoff AJ, Enquist BJ, Elser JJ, Fagan WF (2005) Plant allometry, stoichiometry and the temperature-dependence of primary productivity. Global Ecol Biogeogr 14:585-598

Kirby R M 1971 Soil Survey of Durham County, North Carolina. USDA Soil Conservation Service.

Knops JMH, Bradley KL, Wedin DA (2002) Mechanisms of plant species impacts on ecosystem nitrogen cycling. Ecol Lett 5:454-466

Lavorel S, Garnier E (2002) Predicting changes in community composition and ecosystem functioning from plant traits: revisiting the Holy Grail. Funct Ecol 16:545-556

Lin YF, Jing SR, Wang TW, Lee DY (2002) Effects of macrophytes and external carbon sources on nitrate removal from Zgroundwater in constructed wetlands. Environ Pollut 119: 413-420

Lowrance R, Hubbard RK (2001) Denitrification from a swine lagoon overland flow treatment system at a pasture-riparian zone interface. J Environ Qual 30:617-624

Mack RN, Simberloff D, Lonsdale WM, Evans H, Clout M, Bazzaz FA (2000) Biotic invasions: Causes, epidemiology, global consequences, and control. Ecol Appl 10:689-710

Martin K, Parsons LL, Murray RE, Smith MS (1988) Dynamics of soil denitrifier populations - Relationships between enzyme-activity, most-probably-number counts, and actual N-gas loss. Appl Environ Microbiol 54:2711-2716

Maynard DG, Kalra YP (1993) Nitrate and Exchangeable Ammonium Nitrogen. In: Carter MR (ed) Soil Sampling and Methods of Analysis. Lewis Publishers, Boca Raton, USA, pp 25-38

McCune B and Grace J B 2002 Structural Equation Modeling. In Analysis of Ecological Communities. MjM Software Design, Gleneden Beach, Oregon.

McCune B and Mefford MJ 1999 PC-ORD. Multivariate Analysis of Ecological Data. Version 4.41. MjM Software, Gleneden Beach, Oregon, U.S.A.

McGill BJ, Enquist BJ, Weiher E, Westoby M (2006) Rebuilding community ecology from functional traits. Trends Ecol Evol 21:178-185

McGill BM, Sutton-Grier AE, Wright JP (2010) Plant trait diversity buffers variability in denitrification potential over changes in season and soil conditions. PLoS One 5:e11618

Melillo JM, Aber JD, Muratore JF (1982) Nitrogen and Lignin Control of Hardwood Leaf Litter Decomposition Dynamics. Ecology 63:621-626

Millennium Ecosystem Assessment 2005 Ecosystems and Human Well-Being: Biodiversity Synthesis. World Resources Institute.

Mitsch WJ, Gosselink JG (2000) Wetlands, 3rd edn. John Wiley and Sons, Inc., New York, NY, USA

Moraghan JT, Buresh R (1977) Correction for Dissolved Nitrous-Oxide in Nitrogen Studies. Soil Sci Soc Am J 41:1201-1202

Naeem S, Wright JP (2003) Disentangling biodiversity effects on ecosystem functioning: deriving solutions to a seemingly insurmountable problem. Ecol Lett 6:567-579
Owensby CE, Ham JM, Knapp AK, Auen LM (1999) Biomass production and species composition change in a tallgrass prairie ecosystem after long-term exposure to elevated atmospheric CO2. Global Change Biol 5:497-506

Parsons LL, Murray RE, Smith MS (1991) Soil denitrification dynamics - Spatial and temporal variations of enzymeactivity, populations, and nitrogen gas loss. Soil Sci Soc Am J 55:90-95

Patra AK, Abbadie L, Clays-Josserand A, Degrange V, Grayston SJ, Guillaumaud N, Loiseau P, Louault F, Mahmood S, Nazaret S, Philippot L, Poly F, Prosser JI, Le Roux X (2006) Effects of management regime and plant species on the enzyme activity and genetic structure of N-fixing, denitrifying and nitrifying bacterial communities in grassland soils. Environ Microbiol 8:1005-1016

Pinay G, Barbera P, Carreras-Palou A, Fromin N, Sonie L, Couteaux MM, Roy J, Philippot L, Lensi R (2007) Impact of atmospheric $\mathrm{CO} 2$ and plant life forms on soil microbial activities. Soil Biol Biochem 39:33-42

R Development Core Team (2008) R: A Language and Environment for Statistical Computing. R Foundation for Statistical Computing, Vienna, Austria

Reddy KR, Patrick WH, Lindau CW (1989) NitrificationDenitrification at the Plant Root-Sediment Interface in Wetlands. Limnol Oceanogr 34:1004-1013

Reich PB, Walters MB, Ellsworth DS (1992) Leaf Life-Span in Relation to Leaf, Plant, and Stand Characteristics among Diverse Ecosystems. Ecol Monogr 62:365-392

Reich PB, Tjoelker MG, Machado JL, Oleksyn J (2006) Universal scaling of respiratory metabolism, size and nitrogen in plants. Nature 439:457-461

Schipper LA, Harfoot CG, McFarlane PN, Cooper AB (1994) Anaerobic decomposition and denitrification during plant decomposition in an organic soil. J Environ Qual 23:923928

Smith MS, Tiedje JM (1979) Phases of denitrification following oxygen depletion in soil. Soil Biol Biochem 11:261-267

Steers RJ, Funk JL, Allen EB (2011) Can resource-use traits predict native vs. exotic plant success in carbon amended soils? Ecol Appl 21:1211-1224

Steltzer H, Bowman WD (1998) Differential influence of plant species on soil nitrogen transformations within moist meadow Alpine tundra. Ecosystems 1:464-474

Storer DA (1984) A simple high sample volume ashing procedure for determination of soil organic matter. Communications in Soil Sciene and Plant Analysis 15:759-772

Suding KN, Lavorel S, Chapin FS, Cornelissen JHC, Diaz S, Garnier E, Goldberg D, Hooper DU, Jackson ST, Navas ML (2008) Scaling environmental change through the community-level: a trait-based response-and-effect framework for plants. Global Change Biol 14:1125-1140

Sutherst RW (2000) Climate change and invasive species: A conceptual framework. In: Mooney HA, Hobbs RJ (eds) Invasive species in a changing world. Island Press, Washington, D.C, pp 211-240

Sutton-Grier AE, Megonigal JP (2011) Plant species traits regulate methane production in freshwater wetland soils. Soil Biol Biochem 43:413-420

Sutton-Grier AE, Ho M, Richardson CJ (2009) Organic amendments improve soil conditions and denitrification in a restored riparian wetland. Wetlands 29:343-352 
Sutton-Grier AE, Wright JP, McGilll BM, Richardson CJ (2011) Environmental Conditions Influence the Plant Functional Diversity Effect on Potential Denitrification. PLoS One 6: e16584

Templer P, Findlay S, Lovett G (2003) Soil microbial biomass and nitrogen transformations among five tree species of the Catskill Mountains, New York, USA. Soil Biol Biochem 35:607-613

Tilman D, Knops J, Wedin D, Reich P, Ricthie M, Siemann E (1997) The Influence of Functional Diversity and Composition on Ecosystem Processes. Science 277:1300-1302

Tilman D, Reich PB, Knops J, Wedin D, Mielke T, Lehman C (2001) Diversity and Productivity in a Long-Term Grassland Experiment. Science 294:843-845

Verville JH, Hobbie SE, Chapin FS, Hooper DU (1998) Response of tundra $\mathrm{CH} 4$ and $\mathrm{CO} 2$ flux to manipulation of temperature and vegetation. Biogeochemistry 41:215-235

Vitousek PM (1997) Human domination of Earth's ecosystems (vol 277, pg 494, 1997). Science 278:21-21

Wardle DA (2002) Communities and Ecosystems: Linking the Aboveground and Belowground Components. Princeton University Press, Princeton

Wardle DA, Barker GM, Bonner KI, Nicholson KS (1998) Can comparative approaches based on plant ecophysiological traits predict the nature of biotic interactions and individual plant species effects in ecosystems? J Ecol 86:405-420

Wardle DA, Bardgett RD, Klironomos JN, Setala H, van der Putten WH, Wall DH (2004) Ecological linkages between aboveground and belowground biota. Science 304:1629-1633

Wedin DA, Tilman D (1990) Species Effects on Nitrogen Cycling - a Test with Perennial Grasses. Oecologia 84:433-441

Westoby M, Wright IJ (2006) Land-plant ecology on the basis of functional traits. Trends Ecol Evol 21:261-268

Wittebolle L, Marzorati M, Clement L, Balloi A, Daffonchio D, Heylen K, De Vos P, Verstraete W, Boon N (2009) Initial community evenness favours functionality under selective stress. Nature 458:623-626

Wright IJ, Reich PB, Westoby M, Ackerly DD, Baruch Z, Bongers F, Cavender-Bares J, Chapin T, Cornelissen JHC, Diemer M, Flexas J, Garnier E, Groom PK, Gulias J, Hikosaka K, Lamont BB, Lee T, Lee W, Lusk C, Midgley JJ, Navas ML, Niinemets U, Oleksyn J, Osada N, Poorter H, Poot P, Prior L, Pyankov VI, Roumet C, Thomas SC, Tjoelker MG, Veneklaas EJ, Villar R (2004) The worldwide leaf economics spectrum. Nature 428:821-827

Zak DR, Holmes WE, White DC, Peacock AD, Tilman D (2003) Plant diversity, soil microbial communities, and ecosystem function: Are there any links? Ecology 84:2042-2050 